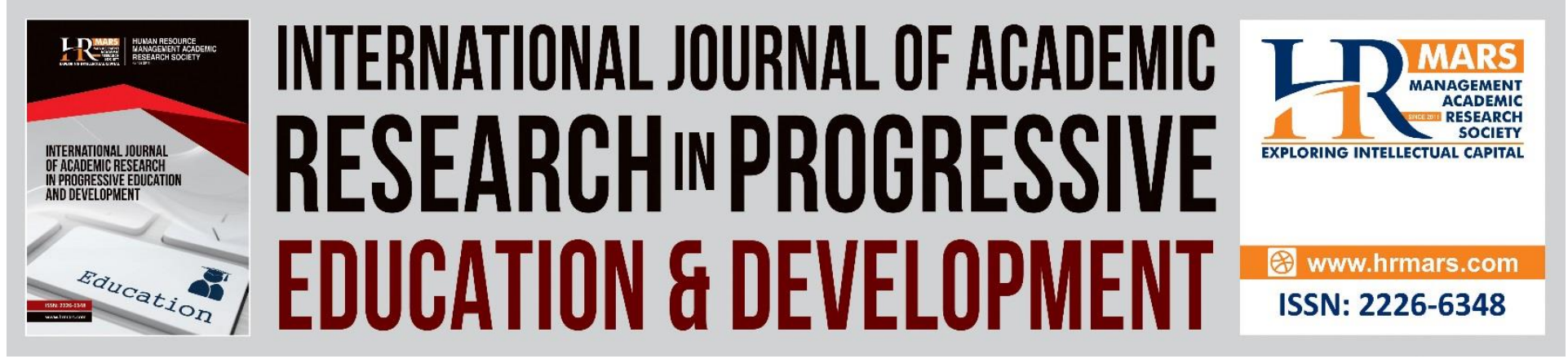

\title{
ESL Learners' Challenges in Speaking English in Malaysian Classroom
}

Saraswathy Kashinathan and Azlina Abdul Aziz

To Link this Article: http://dx.doi.org/10.6007/IJARPED/v10-i2/10355

DOI:10.6007/IJARPED/v10-i2/10355

Received: 09 April 2021, Revised: 29 April 2021, Accepted: 19 May 2021

Published Online: 27 June 2021

In-Text Citation: (Kashinathan, \& Aziz 2021)

To Cite this Article: Kashinathan, S., \& Aziz, A. A. (2021). ESL Learners' Challenges in Speaking English in Malaysian Classroom. International Journal of Academic Research in Progressive Education and Development, 10(2), 983-991.

Copyright: (C) 2021 The Author(s)

Published by Human Resource Management Academic Research Society (www.hrmars.com)

This article is published under the Creative Commons Attribution (CC BY 4.0) license. Anyone may reproduce, distribute, translate and create derivative works of this article (for both commercial and non-commercial purposes), subject to full attribution to the original publication and authors. The full terms of this license may be seen

at: http://creativecommons.org/licences/by/4.0/legalcode

Vol. 10(2) 2021, Pg. 983 - 991

http://hrmars.com/index.php/pages/detail/IJARPED

JOURNAL HOMEPAGE

Full Terms \& Conditions of access and use can be found at

http://hrmars.com/index.php/pages/detail/publication-ethics 


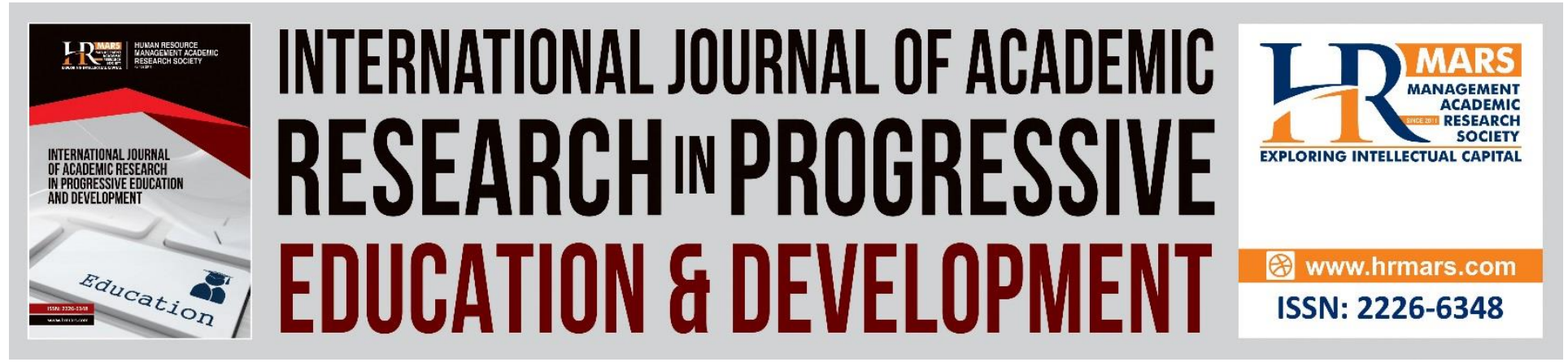

\title{
ESL Learners' Challenges in Speaking English in Malaysian Classroom
}

\author{
Saraswathy Kashinathan and Azlina Abdul Aziz \\ Faculty of Education, Universiti Kebangsaan Malaysia, Selangor 43600, Malaysia \\ Email: p105096@siswa.ukm.edu.my
}

\begin{abstract}
Speaking is a useful language ability that allows speakers and listeners to engage in oral communication for the purpose of transferring and sharing information and developing long-term relationships. English is one of those languages that has the global demand for learners from varied L1 origins at all levels of communication. However, ESL students' developing speaking skills are always regarded as complex and challenging, requiring a great deal of effort to maintain. This article presents a comprehensive overview of published studies of the challenges of ESL learners speaking English from 2014 to 2021 in the Malaysian classroom. This systemic review addresses two questions of research, i.e., what are the challenges faced by ESL learners in Malaysia to speak English and what are the effective strategies to overcome the speaking challenges among the ESL learners? A total of fifteen studies were reviewed in depth. The findings show that ESL students experience both internal and external challenges to speaking English. The findings also reveal useful strategies for overcoming learners' difficulties in speaking the language. The limitations of previous studies were examined in greater depth, as well as future research and practice directions. The study may provide useful information for ESL teachers, English supervisors, administrators, Ministry of Education officials, and, most importantly, learners in the development of speaking abilities.
\end{abstract}

Keywords: ESL Learners, Challenges, Speaking Skills, English Language, Malaysia.

\section{Introduction}

Malaysians have to learn English because it is widely used in a variety of day-to-day activities like commercial enterprise, education, and management. Because Malaysia is one of the very few countries in the world in which English is formally used as a second language, English is regarded as an important part of the education system in the country (Thirusanku and Yunus, 2012). As a result of globalization, the importance of the English language, which has been labelled as the global trade language, has become more abundantly clear. In today's internet and information age, knowing English is essential for achieving international status, as English is the Internet's lingua franca. English is now acknowledged as the world's lingua franca and as the world's most dominant language. English is regarded as a second language in Malaysia and it should be acquired by all Malaysians at school for at least eleven years (Ansari, 2015).

The four linguistic skills in English Listening, speaking, writing, and reading are all significant aspects of the language that must be mastered. For complete communication, the four talents are 


\section{DEVELOPMENT}

Vol. 10, No. 2, 2021, E-ISSN: 2226-6348 @ 2021 HRMARS

required. Listening is usually the first skill learned when learning a language, followed by speaking, reading, and eventually writing. The four skills of language acquisition are a set of four abilities that enable learners to perceive and generate spoken language in order to communicate properly and effectively with others. They're all intertwined to the point where a lack of competence in one will have a direct impact on the others (Christopher, 2016). Though listening, speaking, reading, and writing abilities are all important, speaking skill generally takes precedence over the others since speaking or, in other words, communication occurs frequently in one's everyday life, both in formal and informal contexts. Speaking ability is just as vital as other abilities that must be improved in order to improve communication among target language learners.

Malaysia implemented 21st-century learning in 2014. Communication, cooperation, creativity, and critical thinking, sometimes known as the 4 C's, were highlighted as crucial factors (Ahmad, 2017). Communication is one of the factors of the $4 \mathrm{Cs}$ of 21 st century abilities, thus its relevance is much obvious. In their learning process, students are encouraged to collaborate and communicate with peers or teachers. As a result, in the educational policy, the ultimate goal for many national governments to ensure that students can speak more effectively in order to generate competent English speakers. This will enable them to compete globally (Arif and Amin, 2021).

\section{The Core of successful English-speaking Learners}

For many years, English has been widely spoken and used in Malaysia, to the point where it has automatically become the country's second language. With regard to education, English has become a necessary part of a school and college curriculum in order to overcome communicative difficulties as future experts and professionals for non-native speakers in every discipline (Zhiping \& Paramasivam, 2013). Speaking is a fundamental ability that all language learners should master in addition to their other abilities. Speaking is a difficult skill to perfect, and a competent English speaker is someone who is proficient in the language. Speaking ability is without a doubt one of the most prestigious qualities in the English language. When speaking English, unlike other abilities, one must think swiftly, answer immediately, with little bother and hesitation.

\section{Poor Speaking Skills among ESL Learners}

Malaysian students' lack of communication skills has become a national issue. In Malaysia, the expertise of the ESL is crucial if it wants to establish a generation of global communication. This reflects the objective of the country to become a fully-developed country. The views of instructors on how oral communication skills can be taught in the English language classroom have seldom become a reality, according to previous research. Teachers force students to break the silence before they are ready, and they are required to employ some components of language that they have not yet instinctively learned. As a result of their lack of proficiency in the target language, learners will exhibit poor speaking performance. The beliefs of teachers may not always coincide with their learning environments. There is a disconnect between their pedagogical principles and their instructional methods, which prevents them from putting their beliefs into exercise in the language classroom. However, the findings suggest that teachers continue to use traditional classroom practices including textbook-based instruction. Due to the students' poor competency level, the teacher is forced to revert to more teacher-centered classroom practice (Spawa \& Hassan, 2013). This suggests that, while the teachers are motivated to include communicative language education into their classrooms, they are unable to do so due to the examination's requirements. They do not even have a choice except to prepare the pupils for the exam, which entails providing grammar-based, teacher-centered classroom education. 


\section{DEVELOPMENT}

Vol. 10, No. 2, 2021, E-ISSN: 2226-6348 @ 2021 HRMARS

In research from Yahaya et al (2011), many Malaysian employers claim that our graduates are unable to work because they are unable to communicate in English. When they graduate in Secondary School, several pupils who have studied English as a second language for 11 years do poorly in the speaking of the language. Malaysian students must improve their English acquisition level. Students with a low level of English will certainly lack the soft skills necessary to communicate effectively in an international setting. Speaking skills are one of the language skills that has been causing a lot of controversy and is frequently debated by educators and legislators. The majority of the students passed the English exam, but not all of them can communicate successfully in English. It is fairly obvious that ESL students have little opportunity to use English outside the classroom, especially in the non-English language.

According to Krishnan et al (2012), curriculum designers and policymakers should take a look at the current curriculum, which focuses on workbook drilling to learn grammatical precision. Students are being deprived of this form of learning when it comes to real-world communication. A curriculum that provides adequate opportunity for pupils to build interpersonal and presentation skills is needed to improve students' fluency. The educational system should place a greater emphasis on fluency than accuracy, and pupils should be given several opportunities to present and role play. These types of exercises would help pupils overcome their fear of speaking and improve their fluency. Priority is given to instruction in reading and writing skills as well as the mastery of grammar rules. As a result, English is regarded as a subject with a focus on the language's mechanics rather than finding connections with how it is used in situations of real life. Acquiring English is a learning mechanic, which is separated from communication, by 'fixed' means of using the language (Che Musa et al., 2012). The majority of pupils were found to be victims of typical physiological causes such as classroom fear, shyness, and anxiety. The majority of students were hesitant to speak because they were afraid of speaking in English. Others, on the other hand, felt frightened and shy in front of the class when speaking. Fear, timidity, and worry were the top psychological variables that prevented students from speaking in class. The majority of students were hesitant to speak because they were afraid of speaking in English (Nijat et al., 2019).

2.0 Research Objectives and Research Questions

The major goal of this systematic review is to give to researchers and educators a synthesis of empirical evidence collected in previous relevant studies on the challenges of speaking English among ESL learners in Malaysia, so that more intervention development and research may be done in this field. This study is conducted to answer two research questions:

(a) What are the challenges faced by ESL learners in Malaysia to speak English?

(b) What are the effective strategies to overcome the speaking challenges among ESL learners?

\section{Literature Review \\ Definition of Speaking Skills}

Communication is really important in our lives as humans. We communicate to deliver messages, transmit and exchange information, and report on what is going on in our lives. Speaking as a skill has two main functions: a transactional function in which users communicate and exchange meaningful information, and an interpersonal function in which users build connections. Humans are born with the ability to communicate before learning to read and write. Humans spend far more time communicating vocally with language than they do utilising it in its written form at any given time. Speaking is the most important skill because it is one of the abilities needed to carry on a conversation. Speaking English is difficult because speakers must be proficient in many areas, 


\section{DEVELOPMENT}

Vol. 10, No. 2, 2021, E-ISSN: 2226-6348 @ 2021 HRMARS

including pronunciation, grammar, vocabulary, fluency, and comprehension. If learners have a good command of the English language, they should be able to communicate with others easily and effectively (Leong \& Masoumeh, 2017).

\section{The Notion of English Speaking}

According to Wong Fook et al (2012), Malaysia's history as a former British colony is inextricably linked to the English language, which has been a continual key force in determining national policies, particularly educational policy. During this period English played an important role in management, public sector and commerce with English as a government, administration and trade language. While changing political perceptions have had an impact on its position in education, its dominance as an international and now global language continues to have an impact on Malaysia's socio-cultural structure. The vernacular Malay, Chinese, and Tamil schools coexisted with the English medium institutions. Unsurprisingly, this educational system has produced highly skilled English speakers. There was certainly a decrease in the English skills of pupils due to the switch from English to Malay. This reduction has given rise to concern, since English has become a worldwide language - diplomatic language, international trade, science, ICT and leisure. Malaysia would lose its competitive edge and Malaysians without a strong English speaker management team would not be able to compete on the world arena. There is presently a generation of Malaysians under the age of 50 who were primarily educated in Malay during their school years. As demonstrated in the history of English language learning in Malaysia, English has been influenced to a certain degree by changing political feelings. Nonetheless, its supremacy as a worldwide language continues to have an impact on Malaysia's socio-cultural fabric. Because English is widely used in urban areas, English speakers are often regarded as progressive, modern, and possessing high status and authority.

According to Thornbury (2019), there is not that much of distinction between L1 and L2 speaking abilities. L2 speakers, like L1 speakers, develop speech by thinking, constructing, and finally articulating while also self-monitoring. As a result, speaking skills are practically the same in both languages and should, in principle, be transferrable from one to the other. As simple as this may appear, English teachers are well aware that ESL students find transferring speaking abilities from one language to another to be difficult. Learners require more than genre knowledge of language in order to engage and, in especially, participate in the L2 classroom. They should also be familiar with discourse to organise and connect utterances, as well as interactive talk's turn-taking frameworks. Learners also require pragmatic knowledge, grammar, vocabulary, and phonology; thus the requirement does not end there. Learners can easily become hesitant when faced with such a vast list of requirements. They will lack the confidence to generate $L 2$ utterances, much less use them in everyday communication.

\section{The Importance of English Language}

In Malaysia, English is widely spoken and is the international language of communication. With the growing trend of globalisation, it is expected that this country will confront tougher competition from other countries (Lian and Mardziah, 2014). To remain competitive, Malaysian students must have a strong educational background and training, including the ability to communicate effectively in English. English is widely used in Malaysia's educational system, from primary to tertiary levels, as the most important second language.

Malaysia's national language is Bahasa Malaysia, and the government has agreed to allow English to be taught as a second language in the school system. Malaysia has established a multilingual 


\section{DEVELOPMENT}

Vol. 10, No. 2, 2021, E-ISSN: 2226-6348 @ 2021 HRMARS

education system as one of the Asian countries. Through linguistic educational strategies, the system tries to strike a balance between national and international requirements and problems. (Kirkpatrick \& Gill, 2021).

In Malaysian education, the English language is employed in a variety of ways. In the academic realm, it is the educational lingua franca, as well as a language of communication, instruction, and communication. Some children, on the other hand, continue to treat English as a foreign language, which preventing them from becoming fluent by the end of their school years. Furthermore, because English is not a necessary pass subject, some people see it as unimportant. Despite this, English continues to be a world language in commerce and science, and as a result, it will continue to be one of the languages spoken by educated Malaysians (Darmi et al., 2017). It is also widely employed in a variety of sectors, including medicine, engineering, law, and business. As a result, it is vital for Malaysian students to have a strong command of the English language in order to communicate effectively in academic and professional settings. The capacity to speak effectively in English is one of these soft skills. Indeed, job interviews are now performed entirely in English. As a result, graduates' confidence in speaking is crucial because it demonstrates that they are qualified for the position. In a nutshell, English becomes the second most important language for students, assisting them in their academic pursuits and preparing them for the competitive job market.

\section{The Importance of English Speaking}

Speaking in English can be tough for English language learners, especially if they do not have a solid command of the language (Tom et al., 2013). Speaking is a fundamental language skill that allows a person to engage and socialise with those in his or her immediate social circle. To be a member of a discourse community, a speaker must adhere to its cultural norms, which include the discourse community's values, practises, beliefs, and superstitions. Speaking is one of the key components of the Malaysian Education System's English syllabus, encompassing listening, reading, writing, and grammar. English is widely used in Malaysia for academic and professional purposes. Attending meetings, trainings, or conferences, discussing daily occupations or obligations, giving verbal presentations, and discussing everyday life situations in which the activities are addressed in verbal communication are all examples of verbal communication. Because the native languages are so diverse, English was chosen as a substitute to enable for effective communication (Saleh \& Murtaza, 2018). The ability to communicate well in English has now become a standard criterion for Malaysian graduates seeking employment. Speaking is the foundation of communication and one of the most important linguistic abilities in communication (Yunus and Kaur, 2014).

\section{Learners' Challenges in Speaking English}

For English language learners, speaking in English can be tough, especially if they do not have a good command of the language. A lack of confidence in the English language is the main problem for learners. Involvement of pupils in English-speaking activities demands a certain amount of enthusiasm on their part. In general, intrinsic and extrinsic variables that generate yearning and energy in students to be consistently engaged and devoted to learning and engaging in English activities are classified into intrinsic and extrinsic components (Azlan et al., 2019).

Furthermore, the students are afraid of making mistakes when speaking English. They prefer to avoid speaking the target language and instead express themselves in their original language when they find it difficult to communicate their views in English. The learners' limited vocabulary also makes it difficult for them to communicate in English. Thornbury (2019) in his book, he states that native speakers use 2,500 words to cover 95 percent of their needs. A working knowledge of the 


\section{DEVELOPMENT}

Vol. 10, No. 2, 2021, E-ISSN: $2226-6348$ @ 2021 HRMARS

top 1,500 most common words in English would be beneficial to a learner, while the top 200 most common words will provide a lot of conversational mileage. As a result, when learners lack the vocabulary to even carry on normal and casual conversations in the classroom, they will tend to avoid using L2.

Another challenge that learners face to speak English language is mother tongue interference. Mohtar et al (2015) stated students who have expressed an interest in learning English have been identified. Outside of the classroom, however, the setting did not foster the use of English. During recess, the students interacted in their native language. More interactive activities in the classroom are thought to help them communicate in English with one another. According to Suliman's (2014) research, learners continue to rely on their mother tongue for speech output. The impact of the pupils' mother tongue is evident, as evidenced by the learners' inability to communicate in English, among other aspects. Furthermore, it was observed that students, in addition to producing words, relied on mother tongue translation methods to understand particular instructions. Ultimately, speaking appears to be the most difficult skill among respondents in this study, and they all agree that English is indeed important, particularly as a means of communication. This study also found that long-term exposure to English does not guarantee or entitle students to be competent and fluent language users. The environment is seen as one of the factors contributing to students' lack of competency because they come from a nonEnglish speaking community. Reformation is required to ensure that Malaysian students, particularly those from rural areas, can develop their English language proficiency. Only then will the goal of being understandable among international English speakers be realised.

\section{CEFR and Speaking Skills}

The Malaysian ESL curriculum has undergone several reforms since the implementation of the Malaysian Education Blueprint 2013-2025. The Malaysian Education Blueprint 2013-2015 emphasises the importance of English in the classroom and includes a variety of innovative teaching and learning methodologies to help students enhance their English proficiency in all four areas. The Malaysian Education Blueprint 2013-2015 emphasises the importance of English in the classroom and includes a variety of innovative teaching and learning methodologies to help students enhance their English proficiency in all four areas. Its main objective is to create a "internationally competitive Malaysian English language education system" based on the Common European Framework of Reference for Languages (CEFR). The CEFR (Common European Framework of Reference for Languages) is a benchmark for students' and instructors' language competency levels that allows for comparisons between Malaysia and other nations (Ministry of Education Malaysia, 2015).

The CEFR was created in 2001 to set international standards for foreign language education in order to suit the needs of language learners, academics, and other professions involved in language evaluation, teaching, and learning. Göksu (2015) states that the purpose of the CEFR framework is to improve educational language in terms of reflection, communication, and networking. The CEFR outlines what language learners must do in order to converse in a language. The CEFR (Common European Framework of Reference for Languages) is an international standard that focuses on building learners who can communicate and interact in any language, including English. For categorizing learners' capacity to utilize a language, the framework provides six levels of descriptors. There are three types of language users: skilled (levels C1 and C2), independent (levels B1 and B2), and basic (levels B1 and B2) (levels A1 \& A2). Listening, writing, reading, and speaking skills "can do" statements are thorough descriptors of what students can do (Uri \& Aziz, 2018). 


\section{DEVELOPMENT}

Vol. 10, No. 2, 2021, E-ISSN: $2226-6348$ @ 2021 HRMARS

Darmi et al. (2017) in an article stated according to the Malaysian English According to the CEFR Language Education Roadmap, preschool students should earn A1, primary school students should achieve A2, secondary school students should achieve B1 or B2, post-secondary students should achieve B2, and university students should obtain B2 or C1 upon graduation. In terms of English language competency, this means that between now and 2025, the ministry anticipates an increasing number of Malaysian students from all socioeconomic groups to attain the CEFR-set goal proficiency level for each stage of education (Ministry of Education Malaysia, 2015).

\section{Method}

A systematic literature review is a method of identifying, evaluating, and interpreting all relevant research to a specific research question. This study involved three major phases of systematic literature review: planning the review, conducting the review, and reporting the review which were conducted by Kitchenham (2004). A systematic literature review, she explained, is an important scientific research method for identifying, evaluating, interpreting, and summarising all available research relevant to a specific research question.

The first step is to plan the review. It was carried out in order to determine the need for a review and to create the review protocol. I moved on to the next stage, which was to conduct a review to identify relevant studies that investigated the challenges in speaking English among ESL learners in Malaysia, as well as effective strategies for overcoming the learners' speaking challenges. To extract and synthesise the data, the primary studies were chosen. The third stage was to report on the review by communicating the findings.

Google Scholar, ScienceDirect, Springer e-journals, Ebscohost, ProQuest Education Journals, Educational Resources Information Centre (ERIC), JSTOR, SAGE, and Scopus were used to identify peer-reviewed research studies or articles written in English and published between 2014 and 2021. The database search was narrowed down to studies conducted in Malaysia.

The terms used to search for past related studies in the above databases' keywords fields were Malaysian ESL learners' speaking challenges, low speaking proficiency among Malaysian ESL learners, problems with English speaking in Malaysia, factors causing speaking difficulties among Malaysian ESL learners, and effective strategies to overcome the speaking challenges. In each database, the related terms box was checked, and searches were refined by research domains, research areas, document types, language, and publication years. The initial search produced over 10000 results.

Following that, the titles and abstracts of these studies were screened for the following inclusion criteria:

1. All the participants or respondents in the study could be at their primary, secondary, or tertiary level in Malaysia.

2. The studies should be conducted in teaching English as second language (ESL).

3. The studies should focus on Malaysian ESL learners' challenges speaking English.

4. The studies could employ qualitative, quantitative, or mixed-method research design as more methodologically rigorous studies are needed.

5. The setting of the intervention conducted must be ESL classroom-based.

6 . The studies reviewed must be related to Malaysian context.

It was, however, difficult to exclude journals or articles solely based on the title and abstract of the studies. When the researcher focused on articles related to the Malaysian context, he discovered only a small number of relevant studies. As a result, the introduction and conclusion sections of 
INTERNATIONAL JOURNAL OF ACADEMIC RESEARCH IN PROGRESSIVE EDUCATION AND

DEVELOPMENT

Vol. 10, No. 2, 2021, E-ISSN: 2226-6348 @ 2021 HRMARS

the full article were read in order to select a broader range of studies, and fifteen articles were shortlisted.

\section{Results and Discussion}

Three systematic reviews and twelve prior related research on the issues of Malaysian ESL learners in speaking English from 2014 to 2021 were shortlisted using the above-mentioned procedures for conducting the systematic review. Three of the 15 shortlisted published articles were published in 2019 , and the remaining three were published in 2020. Another three were published in year 2013, 2016 and 2018 respectively. The remaining six were published between 2014 and 2021; with two in year 2014, two in year 2017 and two in year 2021. The empirical evidence to support the challenges faced by ESL Malaysian learners to speak English and the effective strategies to overcome the challenges among the ESL learners are summarised in Table 1 and 2 as follows. 
INTERNATIONAL JOURNAL OF ACADEMIC RESEARCH IN PROGRESSIVE EDUCATION AND DEVELOPMENT

Vol. 10, No. 2, 2021, E-ISSN: 2226-6348 @ 2021 HRMARS

\begin{tabular}{|c|c|c|c|c|}
\hline Year & Article/Study & Number of studies & Research Design & $\begin{array}{l}\text { Results (Approaches andmethods which are } \\
\text { effective to enhance speaking skills) }\end{array}$ \\
\hline 2017 & $\begin{array}{l}\text { Lai-Mei Leong and Seyedeh } \\
\text { Masoumeh Ahmadi } \\
\text { (2017) }\end{array}$ & 33 studies & $\begin{array}{l}\text { Comprehensive } \\
\text { review }\end{array}$ & $\begin{array}{l}\text { PFriendly and cooperative environment to } \\
\text { overcome leamers' difficulties in oral performance } \\
\text { >Use an appropriate method to teach speaking skills } \\
\text { to the learners with different abilities. }\end{array}$ \\
\hline 2019 & $\begin{array}{l}\text { Agatheswari Paneerselvam and } \\
\text { Maslawati Mohamad (2019) }\end{array}$ & 12 studies & $\begin{array}{l}\text { Comprehensive } \\
\text { review }\end{array}$ & $\begin{array}{l}\text { Using social media such as Instagram, flipped } \\
\text { classroom, debates and games as leaming activities } \\
\text { within and outside classroom. }\end{array}$ \\
\hline 2021 & $\begin{array}{l}\text { Thirumangai Rajendran and } \\
\text { Melor Md Yunus (2021) }\end{array}$ & 30 studies & $\begin{array}{l}\text { Comprehensive } \\
\text { review }\end{array}$ & $\begin{array}{l}\text { > Mobile-assisted language leaming (MALL) } \\
\text { propagates the concepts of the constructivism } \\
\text { theory, promotes stress free env ironment, supports } \\
\text { situated learning, and prov ides ease of use. } \\
\text { >Mobile devices' general built-in features and } \\
\text { mobile applications could be used as possible tools } \\
\text { in help ing learners to enhance their speaking skills }\end{array}$ \\
\hline
\end{tabular}

Table 1: Summary of systematic reviews on the challenges faced by ESL learners to speak English in Malaysia 
INTERNATIONAL JOURNAL OF ACADEMIC RESEARCH IN PROGRESSIVE EDUCATION AND DEVELOPMENT Vol. 10, No. 2, 2021, E-ISSN: 2226-6348 @ 2021 HRMARS

\begin{tabular}{|c|c|c|c|c|c|}
\hline Year & Article/Study & $\begin{array}{l}\text { Mumber of } \\
\text { participand/studies }\end{array}$ & $\begin{array}{l}\text { Research } \\
\text { Design }\end{array}$ & Challenges & Effective strategies \\
\hline 2013 & $\begin{array}{l}\text { Amelia Alfred Tom, Aiza } \\
\text { Johari, Awang Rozaimi and } \\
\text { Siti Huzaimah } \\
\text { (2013) }\end{array}$ & $\begin{array}{l}49 \text { pre-university } \\
\text { students }\end{array}$ & $\begin{array}{l}\text { mixed methods } \\
\text { (Questionnaire } \\
\text { and semi- } \\
\text { structured } \\
\text { interview) }\end{array}$ & $\begin{array}{l}\text { >leamers disliked group } \\
\text { discussions and were } \\
\text { uncomfortable speaking in } \\
\text { English. } \\
\text { >the learners were seemingly } \\
\text { unprepared and unaware of } \\
\text { the presentation organization. } \\
\text { >they were also found to } \\
\text { display nervousness when } \\
\text { asked to present in front of } \\
\text { their classmates from the } \\
\text { opposite gender. } \\
\text { >the learners were also not } \\
\text { confident with their ability to } \\
\text { pronounce English words } \\
\text { correctly. }\end{array}$ & $\begin{array}{l}\text { learners should be taught } \\
\text { basic presentation skills } \\
\text { >implementing activities } \\
\text { which focus on improving } \\
\text { students' pronunciation } \\
\text { >fun speaking activities, such } \\
\text { as songs, poems or board } \\
\text { games }\end{array}$ \\
\hline 2014 & $\begin{array}{l}\text { Lim Hooi Lian and Mardziah } \\
\text { Bt Budin } \\
\text { (2014) }\end{array}$ & 200 form four students & Survey & $\begin{array}{l}\text { learners have a moderate level of } \\
\text { English language anxiety and } \\
\text { significant difference between } \\
\text { genders in English language } \\
\text { anxiety. }\end{array}$ & $\begin{array}{l}\text { aware of such socio- } \\
\text { psychological constraints }\end{array}$ \\
\hline 2014 & $\begin{array}{l}\text { Norafini Zulkumain and } \\
\text { Sarjit Kaur } \\
(2014)\end{array}$ & 100 Diploma students & $\begin{array}{l}\text { mixed method } \\
\text { (Questionnaire, } \\
\text { interview) }\end{array}$ & $\begin{array}{l}\text { learners' lack of English language } \\
\text { knowledge }\end{array}$ & $\begin{array}{l}\text { ESL learners learn about } \\
\text { communication strategies } \\
\text { ESL teachers create situations } \\
\text { that can encourage leamers to } \\
\text { produce English oral } \\
\text { interactions }\end{array}$ \\
\hline 2016 & $\begin{array}{l}\text { Johan Severinus Tati, Canne } \\
\text { Paul and Liza Blasius } \\
\text { Golingi } \\
(2016)\end{array}$ & $\begin{array}{l}15 \text { community college } \\
\text { learners }\end{array}$ & $\begin{array}{l}\text { Qualitative } \\
\text { (semi-structured } \\
\text { interview) }\end{array}$ & $\begin{array}{l}\text { lack of vocabulary and fear of } \\
\text { negative evaluation was the major } \\
\text { factors of anxiety in speaking } \\
\text { English language }\end{array}$ & $\begin{array}{l}\text { leamers employed an imitation } \\
\text { strategy to practice speaking in } \\
\text { English and to reduce the fear of } \\
\text { speaking the English language. }\end{array}$ \\
\hline
\end{tabular}


INTERNATIONAL JOURNAL OF ACADEMIC RESEARCH IN PROGRESSIVE EDUCATION AND DEVELOPMENT Vol. 10, No. 2, 2021, E-ISSN: 2226-6348 @ 2021 HRMARS

\begin{tabular}{|c|c|c|c|c|c|}
\hline 2017 & $\begin{array}{l}\text { Nadzrah Abu Bakar, Hafizah } \\
\text { Latiff and Afendi Hamat } \\
\text { (2017) }\end{array}$ & $\begin{array}{l}11 \text { low proficiency ESL } \\
\text { leamers }\end{array}$ & Case study & $\begin{array}{l}\text { learners lack the confidence and } \\
\text { feel shy and apprehensive when } \\
\text { interacting verbally in English } \\
\text { language. } \\
\text { Pearners have limited } \\
\text { opportunities to utilise English } \\
\text { outside the classroom }\end{array}$ & $\begin{array}{l}\text { use of an asynchronous online } \\
\text { discussion forum can be an } \\
\text { effective tool to help the low } \\
\text { proficiency ESL leamers to } \\
\text { develop their speaking skill. }\end{array}$ \\
\hline 2018 & $\begin{array}{l}\text { Rusreena Rusli, } \\
\text { Melor Md Yunus and } \\
\text { Harwati Hashim } \\
\text { (2018) }\end{array}$ & 20 undergraduates & $\begin{array}{l}\text { mixed-method } \\
\text { (Questionnaires } \\
\text { and structured- } \\
\text { interview) }\end{array}$ & $\begin{array}{l}\text { management in teaching, } \\
\text { psychology, as well as, teacher } \\
\text { and peer influence were the } \\
\text { factors that contributed to the low } \\
\text { speaking proficiency of English } \\
\text { among the Malaysian } \\
\text { undergraduates }\end{array}$ & $\begin{array}{l}\text { Plearners should acknowledge } \\
\text { their own efficacy and learn to } \\
\text { make progress rather than } \\
\text { avoiding to speak. } \\
\text { >educators build an English } \\
\text { language learning environment } \\
\text { that suits the students' levels } \\
\text { and interests. }\end{array}$ \\
\hline 2019 & $\begin{array}{l}\text { Khalijah binti Mohd Nor, } \\
\text { Masliza binti Mohd Razali, } \\
\text { Nashrah binti Talib } \\
\text { Nurbarirah binti Ahmad, Siti } \\
\text { Rosnita binti Sakarji, Wan } \\
\text { Aisyah Amni binti Wan } \\
\text { Mohamed Saferdin and } \\
\text { Aishah binti Mohd Nor } \\
\text { (2019) }\end{array}$ & $\begin{array}{l}30 \text { students from higher } \\
\text { learning institution } \\
\text {-Random sampling }\end{array}$ & $\begin{array}{l}\text { qualitative } \\
\text { method } \\
\text { (interview) }\end{array}$ & $\begin{array}{l}\text { learners hesitated to speak } \\
\text { English with their lecturers and } \\
\text { friends in or outside the } \\
\text { classroom because they worried } \\
\text { about making grammatical } \\
\text { mistakes and felt embarrassed of } \\
\text { their low language proficiency. } \\
\text { >they felt self-conscious about } \\
\text { their speaking proficiency } \\
\text { because they have negative } \\
\text { preliminary presumptions about }\end{array}$ & $\begin{array}{l}\text { converse with friends who } \\
\text { have good command of } \\
\text { English or with English native } \\
\text { speakers via Skype, Facebook } \\
\text { or Yahoo Messenger } \\
\text { >watch documentaries and } \\
\text { English movies } \\
\text { practice speaking in front of a } \\
\text { small audience before a } \\
\text { presentation. }\end{array}$ \\
\hline
\end{tabular}


INTERNATIONAL JOURNAL OF ACADEMIC RESEARCH IN PROGRESSIVE EDUCATION AND DEVELOPMENT

Vol. 10, No. 2, 2021, E-ISSN: 2226-6348 @ 2021 HRMARS

\begin{tabular}{|c|c|c|c|c|c|}
\hline & & & & $\begin{array}{l}\text { proficient speakers' views } \\
\text { towards them as being slow } \\
\text { leamers, incompetent and dull, } \\
\text { among others. } \\
\text { >they experienced difficulty } \\
\text { speaking fluently due to } \\
\text { unfamiliarity withs the English } \\
\text { vocabulary. This caused the } \\
\text { respondents to incorporate other } \\
\text { local languages and dialects with } \\
\text { English to ensure the } \\
\text { meanings, intentions or thoughts } \\
\text { are unambiguous }\end{array}$ & $\begin{array}{l}>\text { Consistently practice speaking } \\
\text { English with lecturers and } \\
\text { friends. }\end{array}$ \\
\hline 2019 & $\begin{array}{l}\text { Nazifullah Nijat, Hamza } \\
\text { Atifnigar, Kanageswary } \\
\text { Chandran, Siva Letchumi } \\
\text { Tamil Selvan and } \\
\text { Vijayaletchumy Subramonie. } \\
\text { (2019) }\end{array}$ & $\begin{array}{l}60 \text { pupils in upper } \\
\text { primary }(4,5 \text { and } 6)\end{array}$ & $\begin{array}{l}\text { Survey } \\
\text { (quantitative) }\end{array}$ & $\begin{array}{l}\text { pupils did not have confident to } \\
\text { speak because they felt fear to } \\
\text { speak in English. While some } \\
\text { others were feeling shy and } \\
\text { anxious when speaking in the } \\
\text { class. }\end{array}$ & $\begin{array}{l}\text { interesting speaking activities, } \\
\text { increase the pupils speaking } \\
\text { time, encouraging learning } \\
\text { atmosphere, good rapport } \\
\text { between teacher and students }\end{array}$ \\
\hline 2020 & $\begin{array}{l}\text { Siti Fatimah Omar, Haslinda } \\
\text { Sutan Ahmad Nawi, Tengku } \\
\text { Shahrom Tengku Shahdan, } \\
\text { Rita Wong Mee, Lim Seong } \\
\text { Pek and Fatin Syamilah Che } \\
\text { Yob } \\
(2020)\end{array}$ & $\begin{array}{l}50 \text { primary school } \\
\text { learners } \\
\text { random sampling }\end{array}$ & $\begin{array}{l}\text { Survey } \\
\text { (quantitative) }\end{array}$ & $\begin{array}{l}\text { self-confidence, motivation and } \\
\text { leaming environment affect the } \\
\text { learners' English language } \\
\text { speaking ability }\end{array}$ & $\begin{array}{l}\text { interactive language learning } \\
\text { activities are able to overcome } \\
\text { problems pertaining to } \\
\text { communicative in language } \\
\text { classroom }\end{array}$ \\
\hline 2020 & $\begin{array}{l}\text { N. Kala Nadesan and Parilah } \\
\text { Md. Shah } \\
(2020)\end{array}$ & 30 form three students & $\begin{array}{l}\text { Survey } \\
\text { (quantitative) }\end{array}$ & $\begin{array}{l}\text { students experience speaking skill } \\
\text { is difficult, anxiousness, lack of } \\
\text { confidence, shyness and afraid of } \\
\text { making mistakes while speaking }\end{array}$ & $\begin{array}{l}\text { teacher should also focus on } \\
\text { the speaking opportunities } \\
\text { employed to conduct speaking } \\
\text { lesson }\end{array}$ \\
\hline
\end{tabular}


INTERNATIONAL JOURNAL OF ACADEMIC RESEARCH IN PROGRESSIVE EDUCATION AND DEVELOPMENT Vol. 10, No. 2, 2021, E-ISSN: 2226-6348 @ 2021 HRMARS

\begin{tabular}{|c|c|c|c|c|c|}
\hline & & & & & $\begin{array}{l}\text { speaking task should be a fun } \\
\text { filled activity that would } \\
\text { encourage students to } \\
\text { participate actively } \\
\text { >teachers should upgrade the } \\
\text { teaching skills based on learner } \\
\text { ability to understand the } \\
\text { challenges clearly }\end{array}$ \\
\hline 2020 & $\begin{array}{l}\text { Kamal J I Badrasawi, } \\
\text { Abdulateef Solihu and Tunku } \\
\text { Badariah Tunku Ahmad } \\
\text { (2020) }\end{array}$ & $\begin{array}{l}290 \text { school teachers } \\
\text { undertaking a master's } \\
\text { degree }\end{array}$ & $\begin{array}{l}\text { cross-sectional } \\
\text { survey }\end{array}$ & $\begin{array}{l}\text { >their inadequate linguistic } \\
\text { competency } \\
\text { >inadequate knowledge of the } \\
\text { topic being presented } \\
\text { >negative perception of the } \\
\text { examiners } \\
\text { >linguistic deficiency of } \\
\text { examiners in understanding } \\
\text { their presentation. }\end{array}$ & $\begin{array}{l}\text { lecturers should also motivate } \\
\text { students to use English in the } \\
\text { classrooms. } \\
\text { >avoid intense criticisms when } \\
\text { responding to students' } \\
\text { mistakes. } \\
\text { >students are also encouraged to } \\
\text { increase their use of English } \\
\text { language in different situations } \\
\text { and build on their confidence } \\
\text { as this can lessen their level of } \\
\text { speaking anxiety. }\end{array}$ \\
\hline 2021 & $\begin{array}{l}\text { Tuan Muhammad Hanif } \\
\text { Tuan Ab Hamid \& Faizah } \\
\text { Idrus } \\
\text { (2020) }\end{array}$ & $\begin{array}{l}311 \text { non-national } \\
\text { examination takers } \\
\text { students from three } \\
\text { different schools } \\
\text { (Students aged 13,14 } \\
\text { and 16) }\end{array}$ & $\begin{array}{l}\text { cross-sectional } \\
\text { survey } \\
\text { - quantitative }\end{array}$ & $\begin{array}{l}\text { When listening skill is impeded } \\
\text { by anxiety, it in turn impairs } \\
\text { students' speaking skill }\end{array}$ & $\begin{array}{l}\text { Pteachers need to monitor } \\
\text { students' anxiety level in the } \\
\text { classroom. } \\
\text { >pre-meditated precautions in } \\
\text { reducing anxiety in leaming a } \\
\text { language }\end{array}$ \\
\hline
\end{tabular}

Table 2: Summary of the past related studies which focussed the challenges faced by ESL learners in Malaysia to speak English and the effective strategies to overcome the challenges. 


\section{Challenges Faced by ESL learners in Malaysia to speak English Language}

According to previous researches, the major barriers to ESL learners' speaking skills are a lack of motivation and self-confidence, anxiety, inhibition, and a limited vocabulary knowledge. As a result, identifying potential techniques to overcome ESL learners' obstacles and enhancing their speaking skills is crucial. Previous study has also identified a number of ways that have been proven to be beneficial in overcoming ESL learners' obstacles and enhancing their speaking abilities. The majority of pupils struggle to communicate in English, both in and out of class. It's considerably more distressing if they're expected to speak English before they've mastered the language. A student who believes that nothing should be spoken in English unless it is expressed right would, for the most part, avoid speaking. Because they are terrified of speaking in English, some pupils prefer to keep passive during English courses. Students who are anxious are more likely to expect unpleasant reactions from others, and the situation becomes even worse if they are unable to control their nervousness.

There were three relevant systematic reviews identified (Mei and Masoumeh, 2017; Paneerselvam and Mohamad, 2019; Rajendran and Yunus, 2021) and the findings of these systematic reviews explained the difficulties that Malaysian ESL learners faced when speaking English, and effective strategies for overcoming these difficulties were also discussed in the studies. The studies answered the research questions of the systematic review that addressed earlier in this paper. Mei and Masoumeh (2017) had conducted a comprehensive review of research on 33 research which addressed the problems that affect students' speaking performance of English and some ways to overcome the problems. Mei and Masoumeh (2017), analyzed and discovered a few difficulties in their study, which were about factors influencing learners' English speaking skills. The first issue that students face in class is inhibition. When they want to say anything in the classroom, they are sometimes hesitant. They are terrified of being judged if they make a mistake. They feel embarrassed by the fact that the other pupils are paying attention to them. The second problem is that pupils complain that they don't know what to say and are not really motivated to do so. The third difficulty with the speaking class is the low level of involvement. Because only one student speaks at a time in a large class, each student will have very little time to speak because the other students will be trying to hear him or her. In the speaking class, some students dominate the entire class, while others talk very little or never. Finally, when some students share the same mother tongue, they try to use it in speaking class because it is very easy for them.

The systematic review "Learners' Challenges and English Educators' Approaches in Teaching Speaking Skills in an ESL Classroom" was developed by Paneerselvam and Mohamad (2019). They studied 12 studies that looked at the challenges that ESL learners face when learning speaking skills and the approaches that English teachers take when teaching speaking skills. ESL students experience low motivation and self-confidence, as well as nervousness, inhibition, and a limited vocabulary, according to the researchers. It might be challenging for ESL students to boost their self-esteem, motivation, and anxiety levels. These factors are frequently intertwined, with an increase in worry diminishing self-confidence and motivation, and so affecting performance. As a result, substantial anxiety levels are the main barrier to ESL students adopting the target language, especially in a spoken classroom. In addition, Rajendran and Yunus (2021), had done a 
systematic review on the use of Mobile-assisted Language Learning (MALL) for enhancing speaking skills among ESL learners. In the comprehensive review, they found MALL is one of the most effective strategies for improving the speaking skills of ESL learners who face numerous challenges when speaking English. The study informed readers about the efficacy of using MALL to improve learners' speaking skills. They claimed that MALL employs pedagogical approaches based on constructivist theory principles, provides a stress-free learning environment, supports situated learning, and is simple to use. Furthermore, the benefits of mobile device tools such as built-in features and mobile apps are thought to have a high potential for improving learners' speaking skills.

According to Severinus Tati et al (2016), learners generally experience nervousness when speaking English. They are hesitant, afraid of speaking in front of others, worried about speaking properly, and lack self-confidence when speaking English. This is because the English language is not their second or primary language. They all share an anxiety, including a lack of knowledge of English, a fear that they will misunderstand English, an incompetence to understand English, a fear of making wrong sentences in English, a fear that their peers will laugh, a fear that they will make grammar mistakes while speaking English. In essence, students have shown low English skills, which could contribute to their anxiety. In addition, they expressed reactions during class sessions when making mistakes. The results of the study also showed that these students are mainly anxious about communication concerns and fears of negative view. They have similar causes of anxiety, such as apprehension in public, shyness, and speaking inaccuracy. They also use common coping strategies such as remaining silent and avoiding eye contact. It is not possible to conclude from the observations that students' cultural backgrounds provide them with different reasons for speaking anxiety and different strategies for overcoming it.

The vast majority of second-language students are undoubtedly afraid of being expressed in front of their peers or in public (Yahya, 2011). Most language learners have experienced language anxiety; however, the level of anxiety varies from person to person. Students are usually anxious if they are not native speakers but must learn or use that language. According to a study by Lian and Budin (2014), the majority of students felt moderately anxious when communicating in English with others. Their personal knowledge that they are struggling to understand others and understand themselves is responsible for this type of anguish in second language learning. Students who fear to communicate choose in English classes to be inactive. Due to the fact that students are more concerned with the failure of the test, the resulting process is likely to be stopped, which is critical in the process. Instead of focusing on how their languages can be improved and polished, students would reflect on unreal expectations of perfection. These negative qualities would, without a doubt, influence how they conduct and react in a classroom of the second language, which hinders learning.

Learners hesitated to speak English both within and outside the school with their lecturers and friends because they worried about making grammatical mistakes and were puzzled about their lack of language skill. They were self-conscious about their ability to communicate because they had preconceived views about how proficient speakers saw them as slow learners, incompetent, and unintelligent, among other things. They struggled to communicate fluently because of their 
lack of English vocabulary. Respondents were urged to combine various local languages and dialects with English in order to ensure that their meanings, intentions, or views were understood (Nor et al., 2019). Students' lack of speaking competency is caused by psychological issues, inefficient management, and the influence of teachers' and peers' motivation on their own, according to a study done by Rusli et al (2018). When it came time to speaking in English, the students were nervous and shy, which affected their performance. Students' lack of confidence, as well as a lack of speaking opportunities outside of the classroom, may also prevent them from speaking well. They didn't want to look foolish in front of the class, so they didn't say anything to avoid making a mistake.

According to Zulkurnain and Kaur (2014) research, a few challenges to speaking were identified among ESL learners. Because of their limited vocabulary, the students felt they didn't know how to construct English sentences. Furthermore, students take far too long before producing English sentences. Usually they start with words, before they converse the entire sentence they try to organise into sentences and phrases. They also used incorrect sentence structure and pronunciation on a regular basis. Their research also revealed that learners frequently encountered difficulties due to a lack of target language knowledge. The students delayed their English productions as they wanted to make precise pronunciations of English words. When speaking, some of them admitted to being unsure of their word choice and grammar. According to the findings of the study Nadesan and Md. Shah (2020), students find speaking to be a difficult skill. When the speaking activity is conducted within a short period of time there are difficulties for participants. Students lack confidence and are afraid of being judged harshly by their peers or the teacher if they engage. They also formed a pessimistic perspective concerning their abilities to communicate in the target language. Additionally, being afraid to speak in front of a group can make people feel unmotivated to say what they want to say. Shy youngsters are unable to communicate confidently since they are naturally shy. Learners disliked group discussions and found speaking in English difficult. The learners appeared unprepared and oblivious to the framework of the presentation. When asked to give a presentation in front of peers of the opposing gender, they were similarly found to be nervous. Finally, the pupils were unsure about their capacity to speak English words correctly (Tom et al., 2013).

School teachers enrolling in a master's degree programme, according to Badrasawi et al (2020), experienced anxiety due to speaking nervousness, fear of bad assessment, and worry of making mistakes. They have found that these students are anxious about their inadequate linguistic skills, lack of understanding of the topic, the negative perception of examiners, and others such as the linguistic impairment of the examiners in understanding their presentation. The majority were concerned about their ability to communicate effectively in English. Listening is an input skill used in a second language as part of communication. Input must be obtained before speaking in order to communicate effectively. When anxiety hampers students' listening, they do not receive sufficient speech input. This lack of comprehensible information can cause the students to become anxious, and impair their ability to speak. Hearing anxiety could have an impact on the speech anxiety, as both skills are crucial to oral communication. As a result, if one skill suffers, it is possible that the other would as well. As a result, the language output may be affected by an interruption in the input of a language. The results of this study provide a new perspective on 
pedagogical approaches to anxiety, especially in rural areas, in Malaysian English schools. Note that a decline in anxiety for one skill, such as listening, can reduce anxiety for other related skills, such as speaking when the two anxiety skills are correlated. If there is a link, then reducing or eliminating anxiety in the listening skill may result in a reduction in anxiety in the speaking skill as a result of the input skill's anxiety reduction (Hamid \& Idrus, 2021).

\section{Effective Strategies to Overcome the Speaking Challenges among ESL Learners in Malaysia}

This systematic review discovered a few effective strategies for overcoming speaking challenges among ESL learners. Educators must find a way to overcome psychological barriers such as anxiety and fear in students learning to speak English. Educators must maintain a positive emotional rapport with the students in the classroom. They must create a friendly and cooperative environment in the classroom in order to encourage students to speak the targeted language. Furthermore, authentic activities and materials will assist learners in developing selfconfidence and motivation to speak the language confidently. According to Abu Bakar et al. (2017), online communication media, for example asynchronous online discussion forums, may provide a space and platform for low-skill students to practise their language skills in the second language. This is because the students work and control the learning environment themselves. When ESL students have a possibility to use the language in a non-threatening learning environment, their timidity and apprehension are gradually overcome and they are confident in speaking English. If learners have enough time to think about and practise what they say, but they are not pressured by their teacher or their peers, they will learn the new language unconsciously on their own and if the learners practise consistently, it will happen more quickly. It is assumed that it can encourage and encourage learners to take charge of their own learning. This will lead to the growth of group members' collaborative learning and problem-solving skills. Learners should be taught basic presentation skills such as how to structure an individual presentation, how to start and end a presentation, and verbal and nonverbal communication skills. Moreover, providing activities geared at enhancing students' pronunciation may help them overcome their fear of mispronouncing unfamiliar terms. Additionally, engaging pupils in entertaining speaking activities such as songs, poems, or board games may encourage them to talk, reducing their apprehension (Tom et al., 2013).

According to Rusli et al (2018), psychological issues, poor managerial roles, and the influence of teachers' and peers' motivation on students' motivation can all be addressed if all students recognize their own abilities and endeavour to choose activities that best suit them. To inspire students with limited speaking competence, teachers must develop a classroom climate that enforces authentic activities and materials, as well as relevant and relatable assignments. To increase their speaking abilities, they can adopt a variety of ways. To learn what is required, individuals must first identify their own strengths in public speaking, as well as their own deficiencies. Students can concentrate greater attention on ways to help them overcome their own deficiencies rather than disregarding them. Following that, students must take steps to improve their own public speaking skills. Students developed their own techniques for learning English, such as reading English books, watching and listening to English movies and songs without subtitles. Aside from all of that, students recommend that lecturers employ a range of approaches and engaging exercises, as well as incorporating technology into speaking lessons. 
Speaking is an important part of learning and teaching English. Unfortunately, the teaching of speaking has been neglected, and the teaching process consists of a series of monotonous strategies and exercises such dialogue memorization and drilling. As a consequence, the goals of the speaking lesson in this day and age should be to strengthen students' communication abilities and generate pupils who can express themselves. Interactive exercises, according to many linguists and TESL teachers, are the best approach for pupils to learn to speak. CLT (Communicative Language Teaching) can be utilised to carry out and achieve the goals of speaking lessons. Instead of the conventional classroom setting, students must be exposed to real-world events. Students will learn how to communicate in English with their professors and peers using this strategy. This occurs when students work in groups or pairs to finish a job with the help of the teacher. In this field of study, there are various options are available for further research.

In Tom et al (2013) study, students should learn fundamental presentational skills, for instance the way to structure a single presentation, how to start and finish a presentation and the ability to communicate verbally and nonverbally. In addition, it may be possible to alleviate their concern that they will not be able to pronounce unfamiliar words through their activities designed to improve pronunciation. In addition, the use of fun speech activities, such as songs, poems and board games, can encourage students to speak and reduce their level of anxiety. Making friends with their classmates, discussing their feelings of worry, and practising English with them might help language learners overcome their fear of public speaking. Teachers can also assist students by being kind, facilitative, and upbeat in the classroom, as well as employing a variety of exercises to help students overcome their fear of speaking English (Severinus Tati et al., 2016).

\section{Conclusion}

The learners' limited vocabulary is the most significant factor contributing to their difficulties speaking English. Natural shyness, diffidence, and fear of embarrassment stymie Malaysian students' efforts to learn English. Learners miss out on the opportunity to improve their communication skills and overcome psychological barriers. Students rarely speak the language in school for fear of being mocked for attempting to be a 'Mat Salleh.' It is widely assumed that if you do not speak Malay language, you are not proud to be a Malaysian. As a result, they withdraw and avoid speaking English. Giving every student the opportunity to practise speaking in English. An English teacher's role is to make their classrooms interactive and student-centered. Everyone is concerned with motivating and inspiring students to speak and write in English. Game changers, for example, are interactive elements in English lessons that pique learners' interest in speaking the language. School administrators, in collaboration with teachers and parents, can establish a welcoming learning atmosphere for children, enhancing their drive to learn and speak the language and supporting them in overcoming their fears about conversing in it. Teachers should experiment with various methods and techniques of English-speaking teaching to determine which one best suit Malaysian learners' learning and teaching processes. Because of the dramatic and drastic decline in spoken English proficiency among Malaysia's younger generation, serious and immediate intervention is required. As a result, this paper provides 
Vol. 10, No. 2, 2021, E-ISSN: 2226-6348 @ 2021 HRMARS

insights for English teachers, English supervisors, administrators, and Ministry of Education staff to overcome these challenges in developing EFL learners' learning and speaking skills.

\section{Limitations of the Study}

There were certain limitations in this study that need be addressed in the future if researchers want to delve more into this matter. Applying quantitative methods, like survey questions, could limit the key areas researchers can examine in qualitative case studies. Only 15 papers were examined in this study. However, there may be additional articles from other databases. The authors of the current study only examined at publications from a few databases due to time restrictions. It would be fascinating to expand the research to include more perspectives from different scholars, since the results might either enhance the findings of this study or show different results with different streams of thinking.

\section{Recommendations for Future Research and Practice}

This comprehensive study of the literature has given education a fresh viewpoint, especially in the teaching and learning of English language speaking skills. In the future, more research should be done to explore characteristics that influence students' challenges speaking English in a broader geographical region, diversified learning environment, and various race. Future studies also suggest using a range of high-level English-speaking students to group's success study data and to make critical comparisons of the reasons and factors affecting the achievement and ability of students to speak in their target language. In most of the studies, data collected by questionnaire were taken as a quantitative approach. It is therefore suggested that in future research a qualitative research approach should be used. This can be achieved by conducting a semi-structured student interview and observational and document analysis in order to gain a larger body to explore the factors and reasons that contribute to the difficulties of students speaking English.

\section{References}

Abu Bakar, N., Latiff, H., \& Hamat, A. (2017). Enhancing ESL Learners Speaking Skills through Asynchronous. Asian Social Science, 9(9), 224-233.

Ahmad, R. K. (2017). Handbook of 21st Century Learning Implementation [E-book]. Institut

Aminuddin Baki Ministry of Education Malaysia Kompleks Pendidikan Nilai. Retrieved from http://eprints.iab.edu.my/v2/502/1/preparing\%20schools\%20final\%20with\%20cover.pdf

Ansari, M. S. (2015). Speaking Anxiety in ESL/EFL Classrooms: A Holistic Approach and Practical Study. International Journal of Educational Investigations, 2(4), 38-46.

Azlan, N. A. B., Zakaria, S. B., \& Yunus, M. M. (2019). Integrative Task-Based Learning: Developing Speaking Skill and Increase Motivation via Instagram. International Journal of Academic Research, 9(1), 620-636.

Badrasawi, K. J., Solihu, A., \& Ahmad, T. S. (2020). Second Language Speaking Anxiety Among Malaysian Postgraduate Students at a Faculty of Education. International Journal of Education \& Literacy Studies, 8(2), 54-61.

doi: https://doi.org/10.7575/aiac.ijels.v.8n.2p.54 
Christopher, A. A. (2016). Overcoming Impediments to Learning the Four Language. Advances in Language and Literary Studies, 7(1), 161-167.

Darmi, R., Saad, N. S., Abdullah, N., Puteh-Behak, F., Zakaria, Z., \& Adnan, J. N. (2017). Teachers' Views on Students' Performance in English Language Proficiency Courses Via CEFR Descriptors. IJAEDU- International E-Journal of Advances in Education, 3(8), 363-370.

Göksu, A. (2015). European Language Portfolio in Turkish High Schools: Attitudes of EFL Students. Reading Matrix: An International Online Journal, 15(1), 121-132.

Hamid, T. M. H. T. A., \& Idrus, F. (2021). A Correlational Study of the English Listening and Speaking Anxiety in Rural Areas. English Language Teaching, 14(2), 9-19. doi: https://doi.org/10.5539/elt.v14n2p9

Khan, K. S., Kunz, R., Kleijnen, J., \& Antes, G. (2003). Five steps to conducting a systematic review. Journal of the Royal Society of Medicine, 96(3), 118-121. doi: https://doi.org/10.1258/jrsm.96.3.118

Kirkpatrick, A., \& Gill, S. K. (2021). English in Asian and European Higher Education [E-book]. The Encyclopedian of Applied Linguistics: Blackwell Publishing Ltd. doi: https://doi.org/10.1002/9781405198431.wbeal0383.pub2

Kitchenham, B. (2004). Procedures for Performing Systematic Reviews. Technical Report TR/SE0401, Department of Computer Science, Keele University and National ICT, Australia Ltd, 2004. Joint Technical Report.

Retrieved from https://www.inf.ufsc.br/ aldo.vw/kitchenham.pdf

Krishnan, G., Nair, S., Abdul Rahim, R., Setia, R., Husin, N., Sabapathy, E., Abd Jalil, N. A., Mohd Razlan, R., Mohamad, R., Mat So'od, S. M., Md Yusoff, N. I., Mohamed, N. M., \& Abu Seman, N. (2012). Malaysian Graduates English Adequacy in the Job Sector. Asian Social Science, 2(4), 143-147. doi: https://doi.org/10.5539/ass.v8n4p143

Lian, L. H., \& Budin, M. (2014). Investigating the Relationship between English Language Anxiety and the Achievement of School based Oral English Test among Malaysian Form Four Students. International Journal of Learning, Teaching and Educational Research, 2(1), 6779.

Mei, L. L., \& Masoumeh, A. (2017). An Analysis of Factors Influencing Learners' English Speaking Skill. International Journal of Research in English Education, 2(1), 2(1), 34-41.

MOE (Ministry of Education Malaysia). (2015). English Language Reform in Malaysia: The Roadmap 2015-2025. Retrieved from

https://www.academia.edu/35736437/The_Roadmap

Mohtar, T. T., Singh, P. C. K., Abdullah, N. Y., \& Mat, M. (2015). Developing the Speaking Skill among ESL Elementary Learners. The Asian Journal of English Language \& Pedagogy, 3, 161-180.

Musa, N. C., Lie, K., \& Azman, H. (2012). Exploring English Language Learning and Teaching In Malaysia. GEMA Online TM Journal of Language Studies, 12(1), 35-51.

Nadesan, N., \& Md. Shah, P. (2020). Non-Linguistic Challenges Faced by Malaysian Students in Enhancing Speaking Skills. Creative Education, 11, 1988-2001.

doi: https://doi.org/10.4236/ce.2020.1110145 
Nijat, N., Atifnigar, H., Chandran, K., Selvan, S., \& Subramonie, V. (2019). Psychological Factors that Affect English Speaking Performance among Malaysian Primary School Pupils. American International Journal of Education and Linguistics Research, 2(2), 64-76.

Nor, K. M., Razali, M. M., Talib, N., Ahmad, N., Sakarji, S. R., Saferdin, W. A. A. W. M., \& Nor, A. M. (2019). Students' Problem in Learning English As A Second Language Among MDAB Students At UITM Malacca. International Journal of Humanities, Philosophy, and Language, 2(7), 1-12. doi: https://doi.org/10.35631/ijhpl.27001

Paneerselvam, A., \& Mohamad, M. (2019). Learners' Challenges and English Educators' Approaches in Teaching Speaking Skills in an ESL Classroom: A Literature Review. Creative Education, 10, 3299-3305.

Rajendran, T., \& Yunus, M. M. (2021). A Systematic Literature Review on the use of Mobileassisted Language Learning (MALL) for Enhancing Speaking Skills among ESL and EFL Learners. International Journal of Academic Research in Progressive Education and Development, 10(1), 586-609. doi: https://doi.org/10.6007/IJARPED/v10-i1/8939

Rusli, R., Yunus, M. M., \& Hashim, H. (Eds.). (2018). Low Speaking Proficiency Among the Malaysian Undergraduates: Why and How? Retrieved from http://conference.kuis.edu.my/pasak3/images/eprosiding1/PASAK3_2220.pdf

Saleh, N. S., \& Murtaza, S. F. (2018). English Language Use in Malaysian Government and Private Civil Engineering Workplaces. International Journal of Education \& Literacy Studies, 6(3), 84-91.

Spawa, C. M. C., \& Hassan, F. (2013). “I doesn't know English": Beliefs and Practices in the Teaching of Speaking in ESL Classroom. Pertanika Journals: Social Sciences and Humanities, 21(2), 449-460. Retrieved from https://core.ac.uk/reader/153820347

Suliman, A. (2014). The Interference of Mother Tongue/Native Language in One's English Language Speech Production. International Journal of English and Education, 3(3), 356366.

Tati, J. S., Paul, C., \& Golingi, L. B. (2016). English Language Speaking Anxiety Among Community College Learners: How Can It Be Overcome? PEOPLE: International Journal of Social Sciences, 2(3), 38-53.

Thirusanku, J., \& Yunus, M. (2012). The Many Faces of Malaysian English. ISRN Education, 2012, 1-14. doi: https://doi.org/10.5402/2012/138928

Thornbury, S. (2019). How to teach speaking [E-book]. Vancouver, B.C.: Langara College. Retrieved from https://www.scribd.com/doc/275587410/Thornbury-How-to-TeachSpeaking-pdf

Tom, A. A., Johari, A., Rozaimi, A., \& Huzaimah, S. (2013). Factors Contributing to Communication Apprehension among Pre-University Students. Academic Journal of Interdisciplinary Studies, 2(8), 356-366. doi: https://doi.org/10.5901/ajis.2013.v2n8p665

Uri, N. F., \& Aziz, M. N. (2018). Implementation of CEFR in Malaysia: Teachers' Awareness and the Challenges. The Southeast Asian Journal of English Language Studies, 24(3), 168-183. doi: https://doi.org/10.17576/3L-2018-2403-13

Fook, W. F., Lee King, S., Su, L. K., \& Yaacob, A. (2012). English use as an identity marker among Malaysian undergraduates. The Southeast Asian Journal of English Language Studies, 18(1), 145-156. 
Yahaya, A., Yahaya, N., Choon Lean, O., Bon, T. A., \& Ismail, S. (2011). Factors contributing to proficiency in English as a second language among Chinese students in Johor Bahru. Elixir Online Journal, 41, 5837-5848.

Arif, Y. Z., \& Amin, A. @M. N. (2021). The Implementation of 21st-Century Skills in the Teaching and Learning Process of Vocational College Teacher. Asian Journal of Research in Education and Social Sciences, 3(1), 144-151. Retrieved from

http://myjms.mohe.gov.my/index.php/ajress/article/view/12900

Yunus, N., \& Kaur, K. (2014). The Use of Indirect Strategies in Speaking: Scanning the MDAB Students. Procedia - Social and Behavioral Sciences, 123, 204-214. doi: https://doi.org/10.1016/j.sbspro.2014.01.1416.

Zhiping, D., \& Paramasivam, S. (2013). Anxiety of Speaking English in Class Among International Students in a Malaysian University. International Journal of Education and Research, 1(11), $1-16$.

Zulkurnain, N., \& Kaur, S. (2014). Oral English Communication Difficulties and Coping Strategies of Diploma of Hotel Management Students at UiTM. The Southeast Asian Journal of English Language Studies, 20(3), 93-112. 